Portland State University

PDXScholar

7-29-1971

\title{
Crystal Structure Determination of $\boldsymbol{\beta}$-Lactoglobulin From Electron Micrographs
}

Richard Roeter

Portland State University

Follow this and additional works at: https://pdxscholar.library.pdx.edu/open_access_etds

Part of the Atomic, Molecular and Optical Physics Commons, Optics Commons, and the Plasma and Beam Physics Commons

Let us know how access to this document benefits you.

\section{Recommended Citation}

Roeter, Richard, "Crystal Structure Determination of $\beta$-Lactoglobulin From Electron Micrographs" (1971). Dissertations and Theses. Paper 1479.

https://doi.org/10.15760/etd.1478

This Thesis is brought to you for free and open access. It has been accepted for inclusion in Dissertations and Theses by an authorized administrator of PDXScholar. Please contact us if we can make this document more accessible: pdxscholar@pdx.edu. 


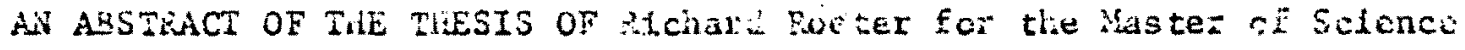
in Physics peesented luig $23,19 \%$

Title: Crystal Structure Determination of $\beta$-Jactoglowulin from Elerstron Milcrograpins

APPROVED BY THE TEMBERS OF TIJE THESIS COMMTZEE:

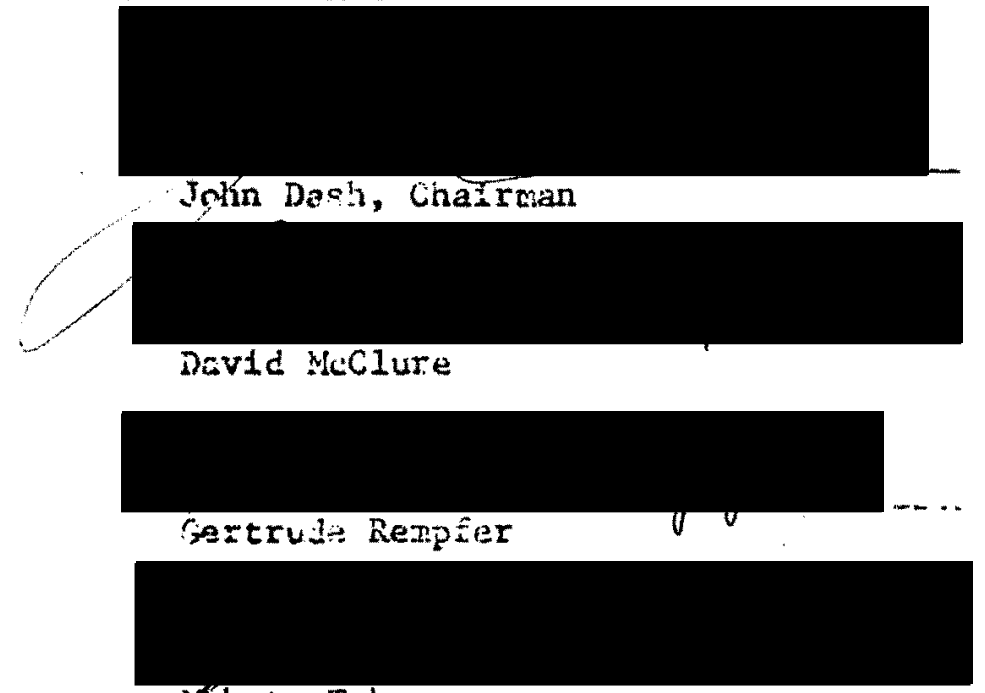

Míkoto Takeo

Often electron micrographs exinibit a cepeating structure. Sometines this repeating struecure satisfies the deftrition of a ritrtal. in thet it has a three dinensional repeating structure. If tide unit cell structure of this repeating structure can be devermined, it can be used to he!rs catagorize different sections of a particular sample. In gome cases, the vsie of uptical diffraction anajysis of electron aicrographs wici: ropetitg structure is a method of determining the unit cell atructure.

Samplas of $p$-iactoglobulic were prepared for viewing j.: the

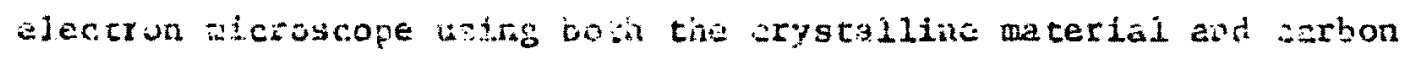


replicas of the crystal surzace. Because the crystalline material was very unstable in tire electron beam, images adequate for use as diffraction gratinga could not be obtained. Electron images from the replicas were used to generate the optical diffraction pazterns in this paper.

The structure of $\beta$-Lactoglobulin has been determined previously by $\mathrm{X}$-ray oittraction analysis, This intormation was used to assist In the interpretation of the optical diffraction patterns.

Electron micrographs and optical diffraction patterns were recorded which were found to be consistent with the stiucture of B-iactoglobulin as determined by $X$-ray diffraction analysis. The unit cej 1 dimensjons were determined to be $a=38 \pm 4 \AA, b=59 \pm 3 \AA$ and $c=102 \pm 12 \AA$ 
CRTSTAZ GTRUCTUEE DETERALVATICN OF S-IAOTOCLORULIN

FKOM ELECTRON MICROGPAPHS

by

RICHAED ROETER

A thesis submitted in partial fulf1llment of the requirements fot the degree of

MASTER OE SCIENCE

in

PHYSICS

Portland State University

1971 
TO IHE OFFICE OF GRADUATE STUDIES:

The members of the Committee approve the thests of RJ chard Roeter presented July 29,1971 ,

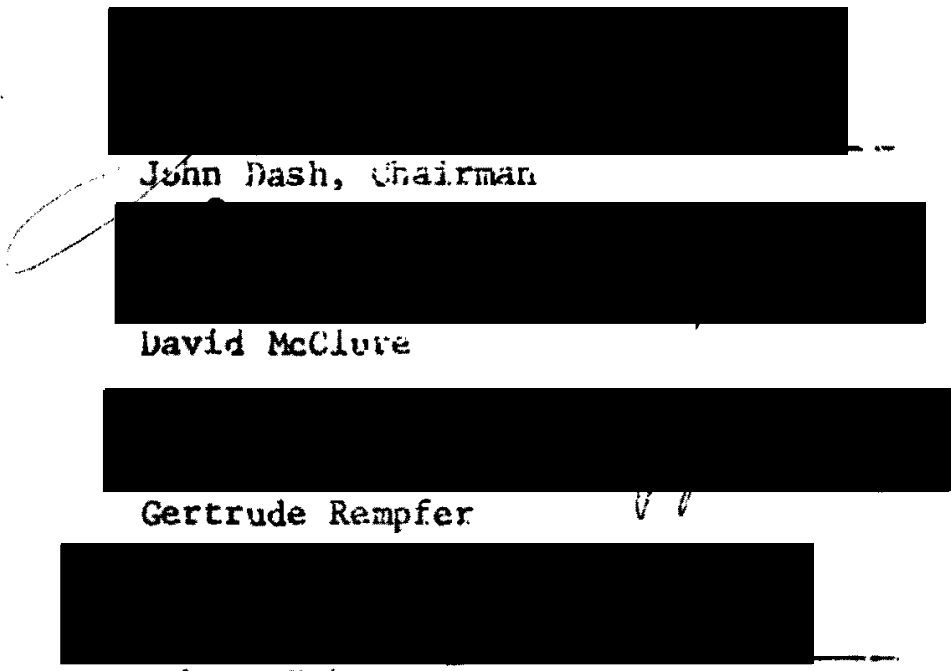

Makoto Takeo

APPROVED:

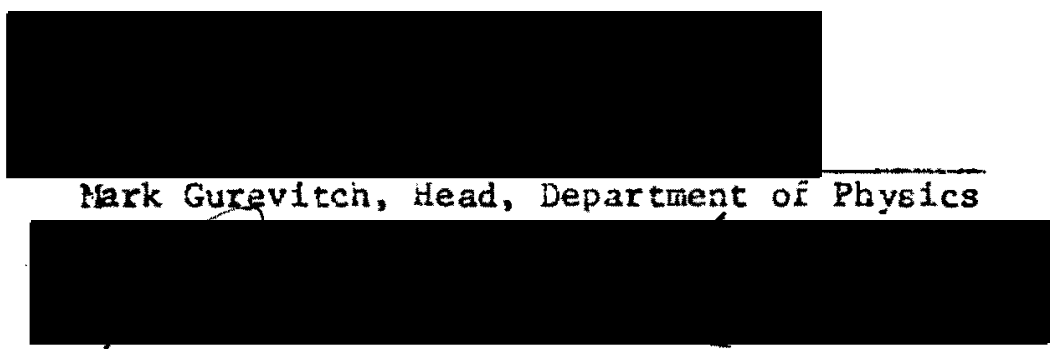

David Clark, Dean of Graduate Studies 


\section{ACKMOWLEDGEMENTS}

The author is grateful to his advisor, Dr. John Dash, for his assistance throughout the project and Dr. Gert:ude Rempfer for her assistance in the intial phases. 
TABLE OF COWTWNIS

PAGE

ACKOHLEDSLEITS. . . . . . . . . . . . . . . . . ili

THS OF THBLES, . . . . . . . . . . . . . . . Y

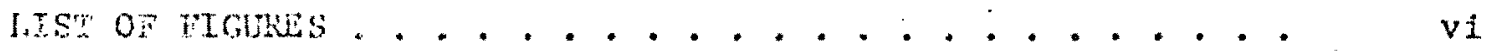

CHAWER

I MTFONCLTON ................... 1

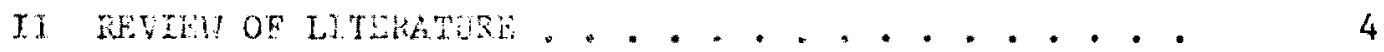

IIJ THOKE . . . . . . . . . . . . . . . 7

Carera Constant Yothol . . . . . . . . . II

Elongation of the Reciprocal Lattice

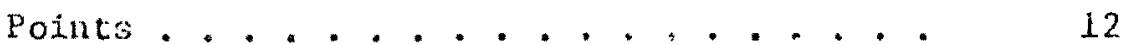

Sources of Error............. 14

IV NeTHOLS AND TEChIQURS . . . . . . . . . 17

Sargle and Samie preparation. . . . . . . 17

Apparatus. . . . . . . . . . . . . 25

$\mathrm{V}$ DATA....................... 29

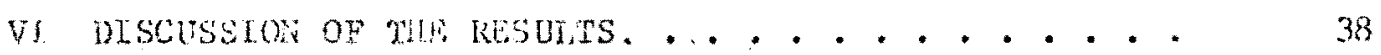

Dita Arabyis . . . . . . . . . . . . 39

Conclusion . . . . . . . . . . . . . . . 39

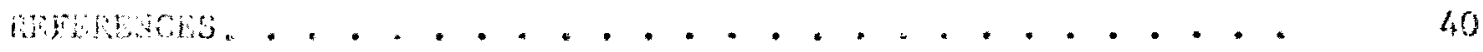




\section{LIST OF TABILLS}

TABIES

PAGE

I. Specifications for Spectra-Physics Model 132

Jaser ... . . . . . . . . . . . . .

II. Comparison of Possible Planes Resolvable in

B-Lactoglobulin Crystal and Experimental Results. . .

31

III. Theoretical and Observed Angles between Diffraction

Planes...................... 
LIST OE FIGURES

FIGURES

PAGE

1. Schematic diagrani showing the relation between the camera lengtii $L$ and the first diffaction maxima on the diffraction pattern. . . . . . . . . .

2. Schematic diagram showing the relation between the elongation of the reciprocal lattice spots and the nunber of scattering slits.............

3. Photograph of a typical collection of 3 -iactoglobulin crystals as seen in the light lujcroscope...... .

4: Photograph shows a bright field image of a single B-Lactoglobulin crystal as recorded using a litachi iis -7 s electron ricroscope. . . . . . . . . .

5. Photograph shows the sane crystal as seen in Figure 4 after about 4 minutes exposure to the electron beart. . . . . . . . . . . . . . . .

6. Photograph of the electron difraction pattern obtalined from the is-watoblobulin crystal in

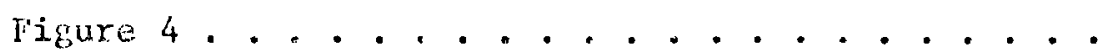

7. Schentatic diagran of the optical difiractoncter apparatus . . . . . . . . . . . . .

a. Photograpl of the electron micrograpin area from which the optical diffraction patters in Figure? 9 was 
obtained with the insert showing the mask area...

9. Photograpi of optical diffraction pattern of B-Lactoglobulin snowing the diffraction maxima ganerated by the (110) and (012) planes.......

10. Pilotograph of the alectron micrograph area from which the optical diffraction pattern in Figure 11 was obtained with the insert showing the mask area. . . . . . . . . . . . . .

11. Photograph of optical diffraction pattern of B-Lactoglobulin snowing tine diffraction maxima generated by the $(001)$ and (100) planes.......

12. Photograph of the electron microgruh area from which the optical diffraction pattern in Figure 13 was obtained with the insert showing the mast: area... . . . . . . . . . . . .

13. Piotograpin of optical diffraction pattern of $\beta$-lactoglobulin shuwing the diffration maxima generated by the $(010)$ and (101) planes. . . . .

14. Photograph of the electron microgroph axea from wich the optical diffraction pattern in Figure 15 was obtained with the insert shoving the nask area. . . . . . . . . . . . . .

15. Photograph of optical diffraction pattern of B-Lactoglobulin showing the diffraction maxima generated by the (110) plane . . . . . . . . 


\section{CHAPTER 1}

\section{INTRODUCTION}

Inclusions which are distinguishable from their surrounding matrix axe of ten found in electron microscope images. Sometimes the arrangemant of these inclusions satisfics the definition of a crystal in that thoy are three dimensional periodic arrays. This repeating structure probably is important, in most cases, either structuraily or runctiona11y, in deteruining the properties of the systems being analysed. For example, in netallurgy, there nigit be a relationship between the inclusion structure and the chenical and physical properties of the material, and in biology, there might be a relationsip between the inclusion structure and the cell structure or organization.

When the inclusion material can be adequately separated from its surrounding natrix, information about fts three dinensional structure can often be determined using X-ray diffraction and/or optical cryscallography teciniques. If the inclusion material canot be separated from its surxounding matrix it is often difficult to charaterize nore than the periodictides and the angular relationships between cia arrays.

The inclusion material and its surround.ug matrix can of ten be prescrved on only sjastoly molif bed wew prepared for viening in the electron microscope, provided the distortion is not too great, the 
electron micrograph intage provides a good repcesentation of a section of the repeating structure. Tive electron microguph inage represents a plane section of the tiree dimensional pericdic structure. Since, in - general, different plane sections of a specimen wil reveal different periodicities, the electron micrograph images nay appear dissimilar when in fact they are different viaws of the same structure. This effect can lead to a great deal of confusion, espacially if these electron micrograph images are to be compared with others found in the same or in different specimens. If the unit cell structure could be determined much of the difficulty could he elininated.

The periodicity of the inclusion material an be measured directly from the print of a high maguificarion electron micrograph. Recenty, Rlug and Dekosier (1) have proposen optical diffraction techniques as a method of determining the thres dimensional linear and angular pazaneters from elcctron uicrographs which have a repeating structure. This was proposed to be accomplished by using the electron micrograph directly as a diffraction grating anc ablysing the resulting oytical diffraction pattern. The uso of optical diffraction for these mosurenents provides a few important advantages over the direct heasuring metrod. First, the optical diffraction method provides an objective and accirate method of measurenent. Second, there are oflen subthe pericdlcities wicil are not readily apparent to the matice ege but are casily secn in the optical diffraction pattern. This, the oftical diffaction patterns of different plane scotions of the three amensional naterial can be recombined in reciprocal space 
to provide information about the unit cell structure. Fourth, the determination of the three dimensional unit cel1 structure can be used to provtde a close approximation of the molecular weight of the Waterial or at leagt place it within a certain range (2).

The-purpose of this research project is to investigate the optical method of structure determination by attempting to determine the unft cell structure of a crystalline material whose unit cell dimensions have been determined by $x$-ray diffraction. 
CHAITER II

REVIER OF LITHRATURE

Generally, repeating scructure in electron rucrograph images is fairly easy to catagorine because a numerical value can be assigned to the various dinensions. Often the interpretation of this data is a far rore complex problen. To extract the maximum amount of information from electron micrograph images with repeating structure, some inrovative techniqus have been developed. One such techuique Las been the use of optical nemoils to both enhance and analyse the repeating structure.

Markhan, Frey and jills (3) have developed a method of investigating rotatinnal periodicities by eqperimposing photograpis of an electron micrograph rotated repeatedly turougi a given angle. When the proper angle is cliosen, the rotational structure is emhanced. Markhail (4) has developed a streboscopic fechique thich also serves to superimpose images in various angular arrays in a maner siniliax to the one above. Linear objects vere treated tn a similar manter by Markha, Hitchborn, Jills and Froy (5). The rechod consists of supertmposine photographs of an electron micrograph which has a repeating structure transiated repeatedly though a proper chosen discance to enhance the reparing structure.

These early mothods of wing optcal mans of enhacing periodic structure have lod reakatiters to eok uther was fu thich optical 
methods could be used to interpret the images with periodic structure in electron micrographs. Klug and Berger (6) have suggested using the electron micrograph of an cbject exhibiting a repeating structure as a diffraction grating and analysing the repeating structure by means of optical diffraction. Using this method to analyse electron micrographs, they wre able to analyse the repat structure, state some conclusions about the negative staining process and distinguish betwetn coutrast arisjing from the "near" and "far" surfaces in the electron nicrographs of TMV helix.

Klug and Berger performed their experinents using an optical diftractometer, an instrunent winch cnables the operator to view the Fourier transform of in image and also to recoustruet inages from their Fourier transforms. The primary use of this instrument has been to assist in the solution of $x-r$ ay diffraction problens (7). Taylor and tipson (7), who have developed this instrument; have made valuable contributions in areas related to optical transforms. Berger (8) has introduced the gas laser as a light source for the optical diffrectoneter. Because of the high intensity of the laser jifght, expesure times for recouding diffraction patterns are greatly reduced. The three dimensional denstity map of the bacteriophage T4 has been reconstructed by Rekosien and ${ }^{2}$ lug (1) using information contained in the alectuon micrograph, its optical diffraction pattern, and complow tecming my further suggested that the projection of

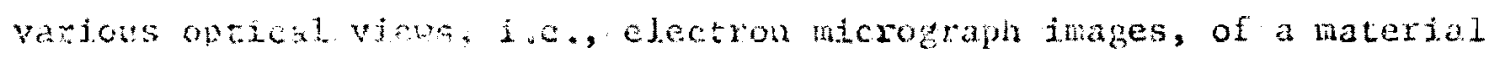

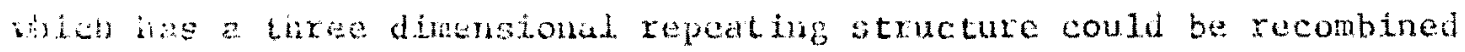


In reciprocal space to deterbine the unit celi structure. Much of the theory ralated to the technique was developed earlier by Bragg (9). The use of optxcal diffraction techniques to determine unit cell sfructure was further developed by the theoretical considerations of Berger (2). Stermlieb and Berger (10) colaborated in the use of recomination techinges to determine the unit celI structure of nitochondrial crystals by optical diffraction analysis of electron micrographs of human liver biopsy specimens, 
CHAPTER III

THEORY

To determine the crystad. structure means to determine the . distribution of scattering mater in the unit cell. For visualization it is convarient to consider the unit cell as made up of discrete scettering elements; however, the true representation is that of a contincous distribution of scattering matter with concentrations of: scatering matter in the region of the unit cell elenents.

One method of analysing this distribution of scattering matter is to express the density function of the crystalline material in terms of a witable Fouring series. The spectrum of the radiation scattered from the crystalline naterial can be used to help detexmine the terms in the series, since each intensity peals in the asfraction patten represents one of the terns of the series. When each term and its coefficient is detertined, the unit cel1. structuxe is determined. Because of the close relationship between the unt cell strucule and its diffraction pacern, as expressed in terms of a Fourler series, a genoral explession of the series is helpful in visualiang the relationshy of tha unt coll structure to the optical diffractun method describet th this parer. The liouriex series can be witan in the following fow when expressed in terms of the reciprocal lattece (9): 
Eq. (1) $\quad \rho(r)=\frac{1}{V} \sum_{n} F(m) e^{-2 \pi L\left(\bar{x} \cdot \bar{r}_{m}^{*}\right)}$

where $\quad \mathrm{Eq} \cdot(2) \quad F(\mathrm{~m})=\int \rho(\mathrm{r}) \mathrm{e}^{2 \pi i\left(\overline{\mathrm{r}} \cdot \overline{\mathrm{r}}_{\mathrm{m}}^{k}\right)} \mathrm{dv}$

$p(r)$ is the density function for a point $(x, y, z)$ in the crystal, $V$ is the volume of the unit cell, $m$ is a single symol used to represent the triple numbers $n, k$ and $l, \bar{r}$ is the vector from the origir of the crystal. lattice to the point $(x, y, z)$ of the crystal lattice, $\bar{r}_{\mathrm{m}}^{*}$ is the vector Erom the origin of the reciprocal lattice to the point $(h, k, 1)$ of the reciprocal lattice, $F(m)$ is the structure factor and $d v$ is the volume of the elementary parallelpiped whose sides are $\mathrm{d} x$, dy and $\mathrm{dz}$. The vector $\bar{r}_{\pi}^{*}(h i k)$ to the point $(h, k, 1)$ of the reciprocal lattice is perpondicular to me planes (ikl) of the crystal lattice and its nagnitude is the reciprocal of the spacing of these planes.

To every spectruta that can be given by a crystal there corresponds one term in the Fourier series. Each such term represents a distribution of scattering natter whose density is given by a plane simple harmonic waveform. There is no spectrum for the zero order, and higher orders from a given set of plates give submultiples of the true lattice spacings of the plane:

The reciprocal lattice and the diffaction patern wijl provide a reprosentation of the spectra given by a crystal lattice. Each term in the fourier series contains an amplitude comonent and a phase conponent, The anditude cononent is the structurefactor $\mathrm{F}(\mathrm{m})$. The value of the phase angle iti given by (9): 
Eq. (3)

$\phi_{\mathrm{m}}=2 \pi\left(\tilde{\mathrm{r}} \cdot \mathrm{F}_{\mathrm{m}}^{*}\right)=2 \pi\left(\overline{\mathrm{r}} \cdot \overline{\mathrm{n}}^{*}\right) / \mathrm{d}_{\mathrm{m}}$

where $\vec{n}^{*}$ is the unit vector in the direction of the reciprocal lattice vector $\bar{r}_{\mathrm{m}}^{*}$ and $d_{\mathrm{j}}$ is the spacing betweer the planes (ak 1 ).

Experinentally, the intensity $|\mathrm{F}(\mathrm{m})|^{2}$, is determined and the phase factor renains urideternined. For this reason and because of the finite number of terias of the Fourier sexies used during analysis, the Fourier series gives information about the unit cell scructure but not the complete structure. Generally other experinental data and theoretical information are combined with the Fourier treatnent to give a good representation of the complete structure.

In 1929 Bragg (9) introduced a method for using Fourier series to analyse crystalline structure. Instead of determining the volune density, one attempts to determine the surface density of all the unit cell scattering matter projected onto a plane. The projection is made along any zone axis and if such a projection can be made on more than one plane, the infornation obtained is of ten sufficient to determine the unit cell structure. The Fourier method is particularily instructive since it providss a mathatical nethod of visualizing the distribution of scittertng wather is the unit cell structure. James (y) has shown, using, Fourier nethids, that the two dimensional projection of the scatcering water of a crystalline structure along a zone axiss onto the veciprocal net corresponds exactly with the distribution of the transtitted amplitude fron a certain two diknsional gratiag heving the same translations. Fin can be 
restated to show the relationship co the optical diffraction method discussed in this paper. If the three dimenstonal crystalline structure can be projected along a zone axis and then transformed into reclprocal space, i.e., by optical diffaction, the reciprocal net rupresents the Fourfer transform of a plane section of the crystalline structure. This Fourter transform passes timough the origin of the reciprocal lattice and lies parallel to the plane of the projection. The electron microscope can be used to project a three dimensional structure onto a plane. Due to the large depth of field of the electron microscope, the whole specimen is brought into focus in the inage plane, Different levels of the specitien cannot be brought into focus excluding other parts of the specinen. Using a goniometer of tilting stage, it is possible to project different viers of the three dimensional unit cell structure (if it is resolvable) along a zone axis onto a plane, i.e., the linage plane.

As was stated earlier the diffraction pattern alone cannot be used to determine the complete unte cell. structure in tems of a lourier series because of the lack of Lnformation about the phase. However, one can analyse the spatial distribution of the diffraction manting to detexthe a repiesentation of the two dinensional projection we the systaline stucture.

To determine the three dimensional structure, one can generate ontfosit diffaction patterns from electron wicrographs which represent two dimensional projectiona of the crystalline structure. One then combres two dimensional. diffruction patterns whicli contaja one line 
in comon, that is, with an identical periodicity. These two diffraction planes intersect each other along tineir common line. Once the angle between the two planes is determined, the relative orientation of the two planes is uniquely determined. A practical twethod of solving this problem is to find a third two dimensional plane wich intersects the first two. The constructed lattice now represents a section of all the unit cell structure in reciprocal space. Once a nypothatical unit ce1d structure in reciprocal space has been constructed, other diffraction patterns of different sections can be used to test for consistency. The unit cell structure in reciprocal. space can then be converted nathematically into real space.

\section{CALER CONSTANR MEMOE}

A ray diagran representing the Frauniofer diffraction patten generated from a double slit is shom in Figure 1. An intensity peak. ocruxs in the diffraction pattern when the diffracted waves interfere corstructively. If $\phi$ is sufficiently small, i.e., less than 6 degrees, the Brigg equation for the first order maximum can be written as

$$
\mathrm{kq} \cdot(4) \quad \lambda=\mathrm{d} \phi
$$

where $d$ is tire spacing of the double slit and $\lambda$ is the wavelength of. the incident radiation. When is siall, is approximately equal to $\theta$ and

$$
\mathrm{Fq} \text {. (5) } \phi=x / 1
$$

where $L$ is the camere lengtin and $x$ is the distance from the center of the difracion patton to the spot to be indexed. Substituting 


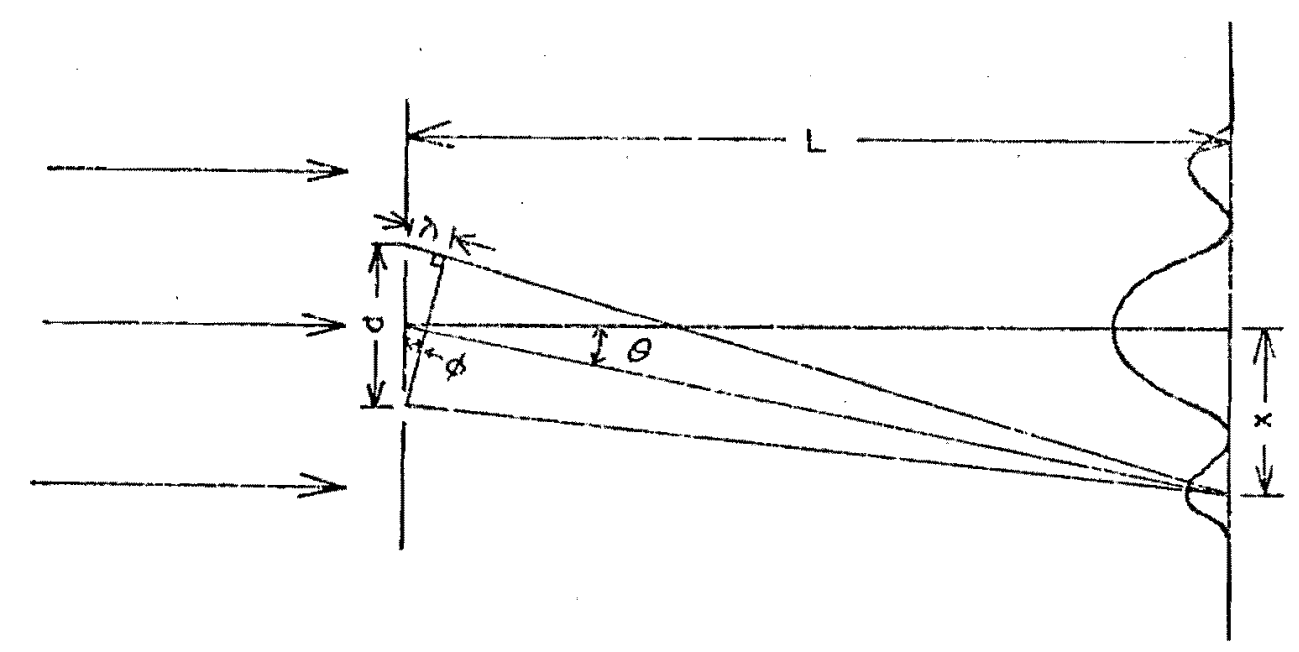

Incident Porallel

Monochromatic

Lighi
Diffroction

Grating
Difiraction

pione

Figure 1. Scheratic diagraa showing the relation becween the came: a length $I$ abl the first diffraction maximum on the ditroction pattori?

Squation 4 into Equation 5, we get the equation

$$
\text { Eq. (6) } \quad L_{i} \lambda=\mathrm{dx}
$$

The tem $L \lambda$ is known as the canera constant and is determined from measurements of $x$ on a diffraction pattem of a substance of accurately known spacing. The procedure to index the diffraction pattein using the concra coustant nothod is to measure the $x$ value for ench spot and calculate its d spacjirg from iguation 6.

11. WLONGATO ON TEL RCLROCAL LATICH POSTS

A ray diagram showing the elongation of a recincocal latice spot genorated Erom a ditraction grating is shon in figre 2. Jenkins and wite (11) list the angular hale widh of any proncipal maxinum for a differotion gruting as 


$$
\mathrm{E} \tau_{\mathrm{i}} \cdot(7) \quad \Delta \theta=\frac{\lambda}{\mathrm{Nd} \cos 0}
$$

where $\Delta t$ is the angular half widh of the diffraction maximut generated from the diffraction grating, $\theta$ is the angle at which a ray leaves the grasiag in Figure $2, \lambda$ j.c the wavelength of the finctdent radiation, d Is the distarce separating the centers of the scattertng slits and $N$ is the number of scattering s3iso.

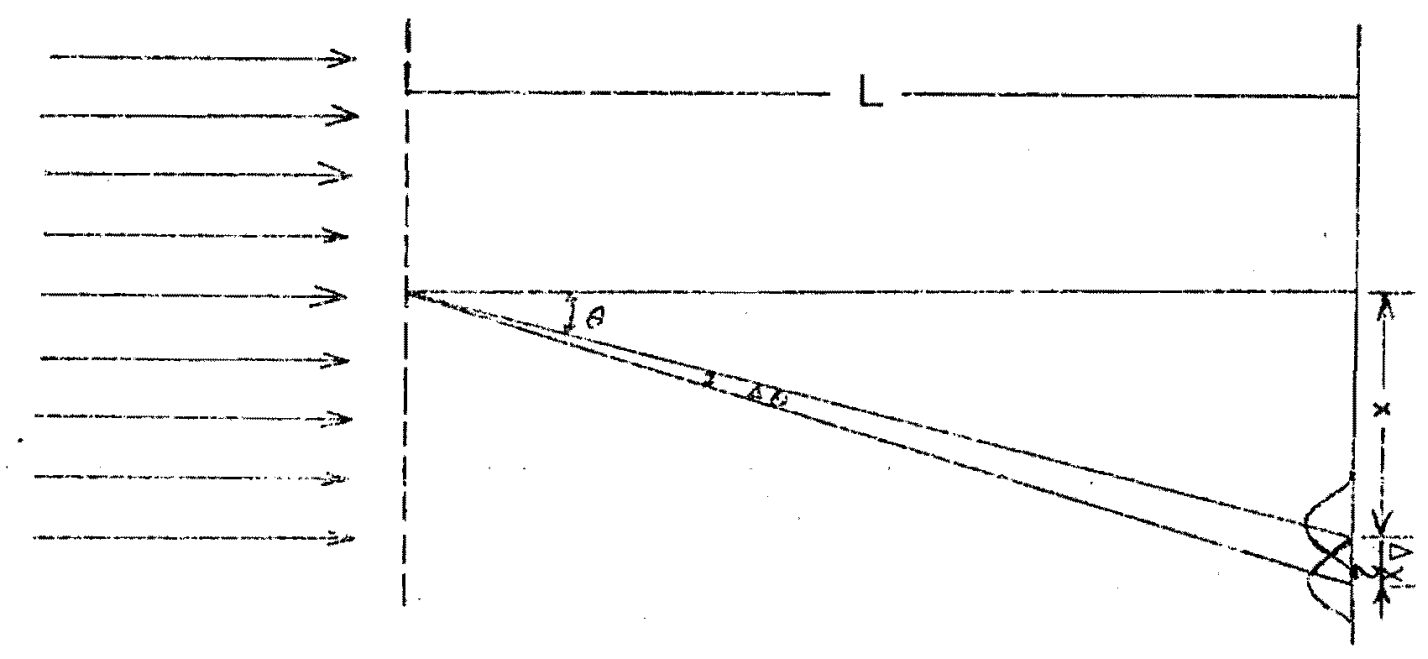

Incident Porallel

Monochromatic

Light

\section{Diffroction \\ Groting}

Diftraction Plane

Fizure 2. Schematic diagram showing the relation between the elongation of the reclprocal lattice spots and the nunise of scattcing slits.

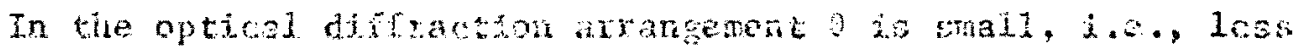

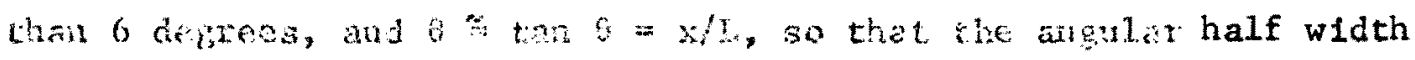
of any principal maxima can be expressed as

$$
\mathrm{Eq} \cdot(3) \quad \Delta \theta=\frac{\Delta \mathrm{X}}{2 \mathrm{~L}}
$$

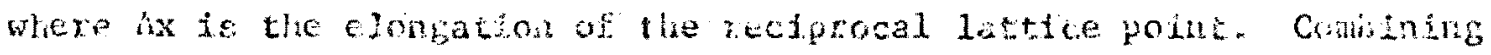
Equatione 6,7 and 8 , the elongenom of the rectprocal latrice point 
can be expressed as

$$
\text { Eq. }(9) \cdot \Delta x=\frac{2 x}{N}
$$

where $x$ is the magnitude of the reciprocal lattice vector from the origin of the diffraction pattern to the diffraction maximum of intereat and can be neasured directly. The value of $A$ can also be detemined experimentally. This can be accomplished by photographirg both the back focal plane and the image plane of the magnifying lens of the optical diffractonter. The inage plane will contain the imge of all the scatering onjects which scatter the radiation from the laser bean of finite djareter. Another method is to prepare a nask for the region from which a diffraction pettern has been obtained in an electron micrograph. The nuber of beatering objects intercepted by the laser beam will depend on the dimensions of the inask in the particular direction related to a difjraction spot. One can photograph the mask area, i.e., using on enlarger, and count the number of scartering objects along the direction rejated to a particular diffraction spot. In general, the valve of $N$ will depend upon the reagnification of the alectron micrograph and the axea in the edertron microgaph exposed to the incident radiation.

\section{SOLRGS OF FRRO?}

Because of inherent difficulties in the diffraction method of andysis and the morous problens associated with the specinen, tio constructed Jatelce will be subject to sone error. Sternlieb and 
Berger (10) Iisted sonce of the inaccuracies associated wth the specinen. Conpression of the material during sectioning can make lattice determination difficult since the analysis is based upon the conbination of reciprocal lattices vith identical periodicties. Some inaccuracies may be due to swelling or shrinking of the specimen duxing fixation and dehydration. Berger (2) states that is some cases there may be wore than one type of crystal lattice in a single specimen. however, if enough sections are analysed some discrepencies should be apparent wich prevents construction of the unit cell structure.

A serious source of error can be related to the type of symmetry of the crystalline material. If the crystalline materlal has a glide or screw axis, the lattice paraneters firy have the wrong dimensions. Hopever, the constructed unt cell is usoful information in these cases because $i t$ is related by sone constant to the real repeating pattern. Dther metrods can be used to determine the value of this constant. The diffraction maxina in the reciprocal lattice are generally rot lattice points. Decause of this there is 'a certain amount of error introduced in combining reciprocal lattices with identieal. poriodicities. When the elunated reciprocal lattices are combined there is a range of orientations possible. The elongation of the reciprocal lactice point cam be matimnaticaldy expressed by Equation 9. This equation shows thet the reciprocal lattice maximum is a point when the nubber of scatcering objects is infinjte. Ideally, the expertiental apparatus swould provide tive largest possible number of scateriag points without producing unwantal other effects. The 
lasor bean diameter can be chosen or else expanded so. that the maxinim number of scattering objects will be intercepted without introducing abberation of distortion of the optical diffraction pattern due to the dinensions of the lens.

For a thin lens the focal point for the rays coming from the outer part of the lens is closer to the lens than the rays frou the inmer part of the lens. This effect cannot be totaliy eliminated but it can be reduced by selecting only the rays near the optical axis. Arother method of increasing the number of scattering points is by selecting an optimur inagrification for the electron micrograpn image. There will be a range of maguification possible for the analysis of electron micrograph inages using optical diffraction. This range will be limited at one extreme by she resolution of the elactron microscope and/or sample preparation and at the other extreme by the numier of scattering objects intercepted by the buxin of radiation of a finte diameter incident on the electron micrograph.

One attenpts to establish the optinum conditions for the deterniogion of the reciprocal lattice. Tuis will generally nean generatigg a difraction patorn which is an optimun between the angle of the diffracted beam being smajl and the number of scattering objtcts being large.

Knowing the number of scattering objects and the magnitude of a particular reciprocal Iatcice vector, the elongation of that point can be detamined. This elongation can be used to indicate the range of possible oxieutations when two diffraction patterns are conbined. 
CAAPTER TY

METHODS AND TECWIQUES

\section{SAMLE AMD SARLE PREPAEATION}

The three dimensionai structure of nany crystals which have a repeating structure which is resolvable with the electron wicroscope has bcen detemined. B-Lachoglobulin is one such crystal.

Aix frited B-Lactoglobulin crystals were obtained fxon the Mamn Research Laboratory. Senti and harner (12) have reported some of the properties of R-lactoglobuzin crystals they have-grown. They reported an average vaiue of $9.8 \%$ water cortent in air arled B-Lectoglobulin crystais with slight variations frow day to day. Senti and Warnet also found that two types of R-Lactoglobulin crystals fowned, both orthorhotabic, but dffexent in habit. One batch had thick rectangular Fabiers sowewhet plongated along the [1.00] and showing (001) dominance. The other batch contained pisms wich were conclderably elongated alorg the [010] tud usidily shoved (100) dowinant, although (001) was

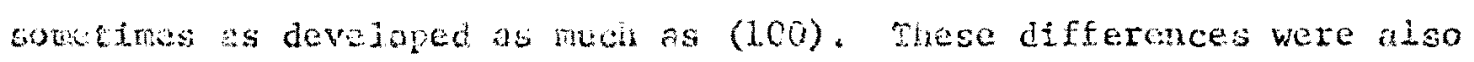
observet by Riley (13). "he optical properties of the B-Lacloghobulin crysuls used in the work reported in this paper were not examined. This inforation to pobaby directy related to the sections observed th the jecton wicroscope becase of the preterential fractuting along

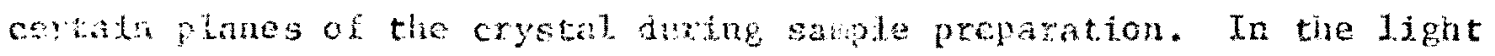


microscope, the crystale appeared to be translucent flakes. Figure 3 shows typical puLactoglobultu crystals as observed with the Iight mierosecpe.

There have been severid reports of the three dinensional unit cell structure of B-Lactoglokulin. There is a certain amount of difference in the values for the lattice paraneters. Much of this discrepency is due to the uncertainty in the water content. For aix aricd crystals crowfoot (14) regorted unit ce11 dinensions of $a=60 \AA$, $b=6.3 \AA, c=110 \AA$, Fankuchen $(15$ ) reporced $a=60 \AA, b=62 \AA$, and $c=111 \AA$, and the values of $a=60.7 \AA, b=61.0 \%$ and $c=112.4 \AA$ were found by Senti and Warner (12). The error in the Senti and Warner lattice paraneters is estinated to be ro greater than $0.5 \%$ (12). To give an idea of the varintion possible in the lattice parameters doe. to the water conten $x$, Senti and warner reported the following valuess for the lattice parameters with crystals having an average water content of $46.2 \%: a=69.29 \AA, b=70.42 \dot{A}$ and $c=156.5 \AA$

The lattice parameters of B-Lactoglobulin are well within the resolution linit of the electron microscope. Dawson (16) has recorded electron tuages thich stion plaves of wate cell dimenstons for 6-iactoglobulin. He reported a view of the (100) face of B-Lactoglobulin cryetal with a periodicity of $\mathrm{c}=105 \pm 5 \AA$. In addition, from a mexeurement of shadow length he detexmined $a=50 \pm 10 A$, with $b$ being udeternbind. Considering that the water content was probably reduced in the cvaporator durtig sample preparation, the results are In good agreesent wh the y-lay diffraction results for the 


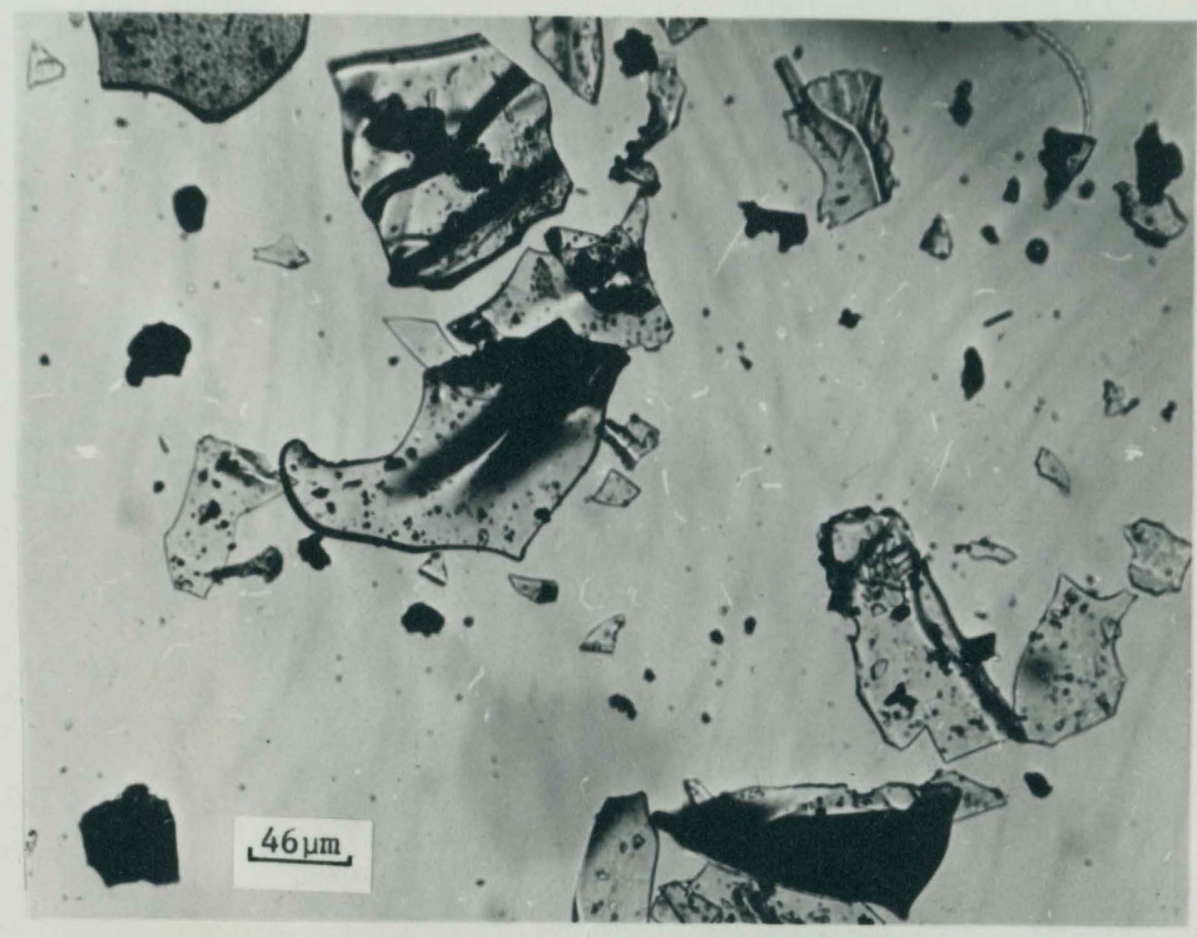

Figure 3. Photograph of a typical collection of -Lactoglobulin crystals as seen in the light microscope. Magnification 240X. 
determination of tize dait cell dimensions.

Initially, an attempt was mide to view the lattice planes of p-lactoglobulin directly and correlate the planes of the crystal with the selected area electon diffration pattern. B-Lactoglooulin crystals were cruched into a very fine powder. This powder was dusted onco a copper mesh gria winch was coated with a thin carbon film substrace. The grid was then shaken to remove any crystals which did not adsere to the carbon film. The crystals were then viewed directly whth SOliv and $125 \mathrm{kv}$ titachi electron nicroscopes. These crystals were very unstable con under very low beam currents, eg. 3 Hamps. Any repeatjug structure to the crystal was not readily apparent. The electron inage cuanged fron daxk to light when viewed with bright field Wh very little concrasi except when gross changes were occurring. No repanting structure vas apparent using dark field imaging. The initial electron diffraction pattern was generally very strong and faded in a sibot lergth of time (generally in a few minutes). These effects made direct viewing of the crystal lattice planes inpossible.

Figure 4 shows a print of a bricht fieli image of a single B-lactoglobulin ciystal. Figure 3 shows a print of a bright field image of the same p-inctophobulin crystal atter exposure to the ejocron bean for above 4 minutes. During this time there were numerous ignalual chonges in contrast cunditons. Not shown in the print is a hato of matorial which bas prosumbly resulted from a reacion of the elechon bean with the B-lactoglobulin cxystal. Dark fiadd jugce lor B-tactoglobulin crystals were recorded but not used 


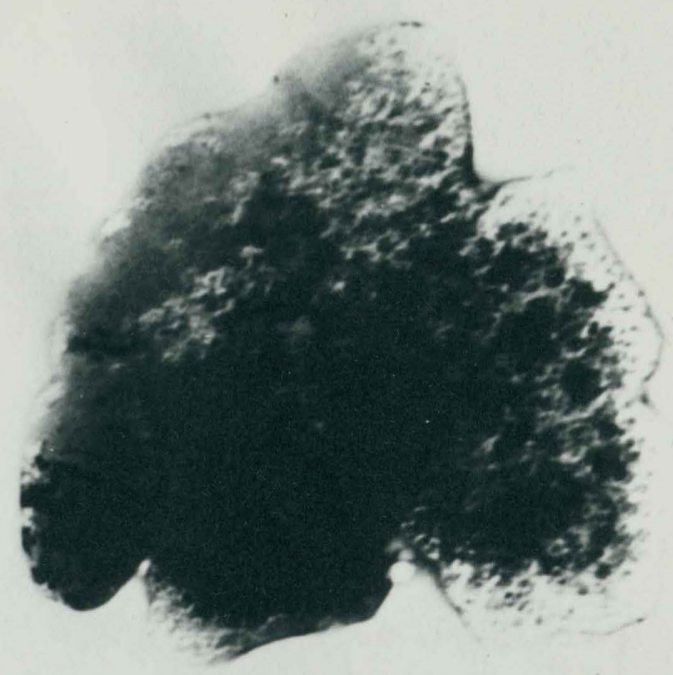

Figure 4. Photograph shows a bright field image of a single B-Lactoglobulin crystal as recorded using a Hitachi HS-7S electron microscope. Magnification 52,500X. 


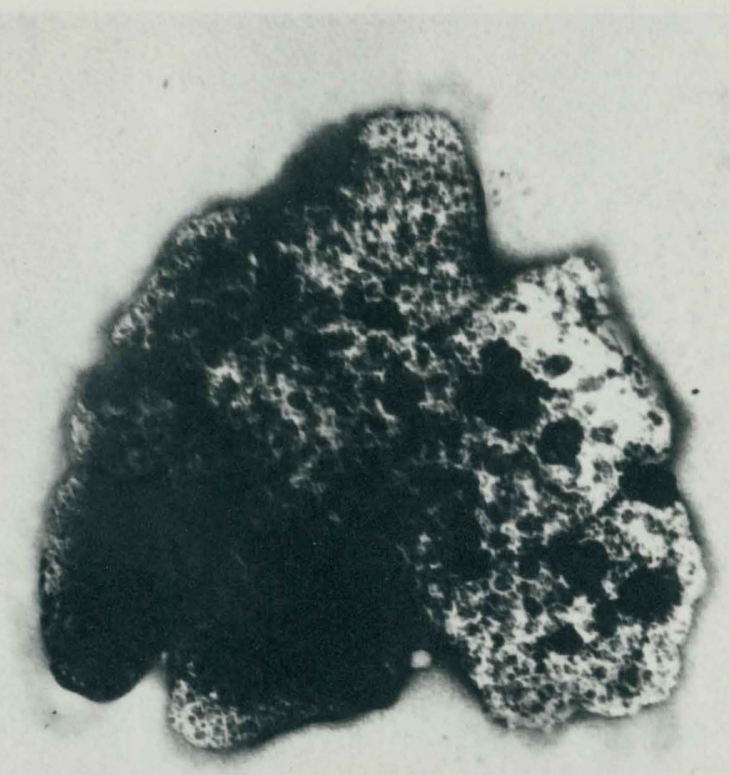

1900A

Figure 5. Photograph shows the same crystal as seen in Figure 4 after about 4 minutes exposure to the electron beam. Magnification 53,500X. 
In this paper. Although the electron difraction pactern had intense scattered beams, the image from these scattered beams did not reveal pexioulcities. Flgute 6 shows a typical electron diffraction pattern obtalied from B-lactoglobulin cryscal.

Ereparaticas for indirect vioving of the crystal plares in the electron mimoscopo were made using a psuedo-replica technique sindlar to that used by Wyckoff (17). B-Tactoglobulin crystals were arusined betwow two glass slides and dusted onto a parlodion filin. An alloy contaluing $30 \%$ platinum $20 \%$ palladinn was shadon cast in a vacuun evapurator onto the cxystals from two directions at right angles to each otier. One direction was elevated $20^{\circ}$ above the horizontal and the obiex direction $45^{\circ}$ above the horizontal. Each shadowsestict deposiced approxinately 40 of the alloy on the crystals. Carbon was then deposited from vertically above the crystals in order to forn a contincous replice film The copper mesh grid was then placed san 10 side up in a dish containing a fine sponge filled with acetone to diseone the parlotion fim. Aftex ten minutes, the copper mish gid was trusferred from the acotone bah to a second dish containirg a fine gionge filled whth a C.1 H solution of sodiam chloride in

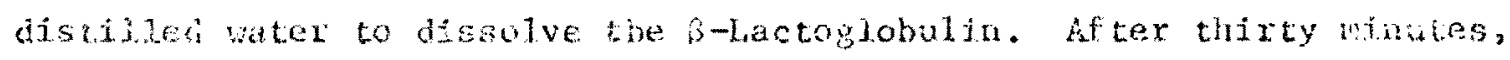
tre copler wesh grid was trangrecred to a that dish containing a fine spoug fillod wich distiled water to rinse the sample. The sample Was turn cenoved from the water ond air dried in preparation for viender the electron microucope. If what pieces of the original materiats athere to the edron suppore, they may be raroved with 


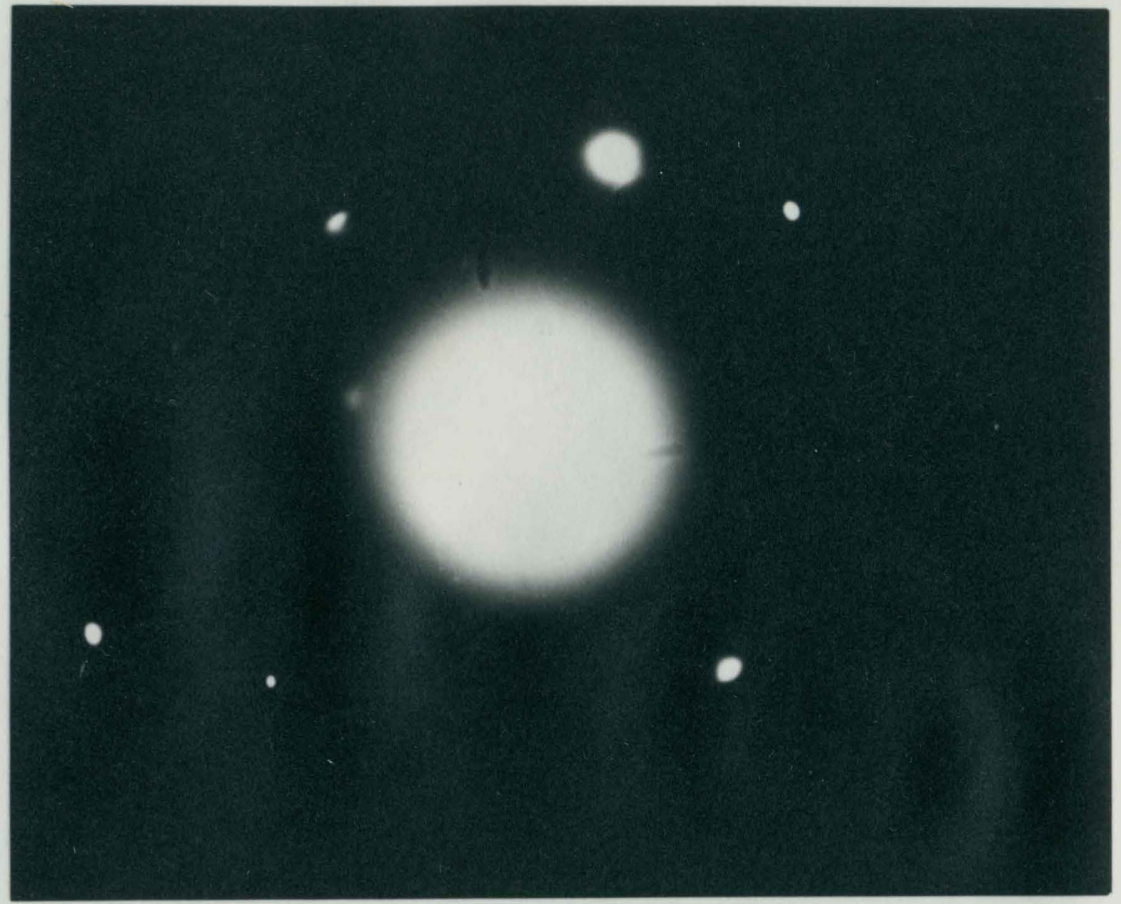

Figure 6. Photograph of the electron diffraction pattern obtained from the $\beta$-Lactoglobulin crystal in Figure 4. 
solvents or, in many cases, left in place, since the structure observed in the electron microscope is mainly that of the inetallic film.

\section{TI. APPARATUS}

The specinens of $\beta$-Lactoglobulin, prepared as described in the previous section wexe viewed with a hs-7s electron microscope at an accelerating potential of $50 \mathrm{kv}$ and photographically recorded on electron image plates. Magnifications of 50,000 to 60,000 times enabled one to obtain electron micrographs with repeating structure. This structure was generally not apparent when viewed directly in the electron microscope. These electron micrographs were used to generate optical diffraction pattems in the apparas described below. Thz optical diffraction pattems were rocorded on Plus $\mathrm{X}$ Pan Professional 4147 filn with exposure tires of about 1 second. In addition, a mask was prepared for each eaction in the electron micrograph from which an optical diffraction pattern was obtained. This was done to identify the section and record the orientation.

A diagran of the optical difiractoneter used to obtain optical Frauhofer diffraction pattems from electron merographs is represented diagramatcally in tigure 8. Light coming from a spectraPhysics Model 132 heliummeon gas laser, whose specifications are 1isted in Table 1, passes through a microscopo objective lens, 10x, and a pinole which form a spatial filtex for expanding and cleaning up the bean, f.e., remoying unwented intenstey variations. $L_{1}$ is a collingting lens that rendors the broxgent light parallel. Next in 


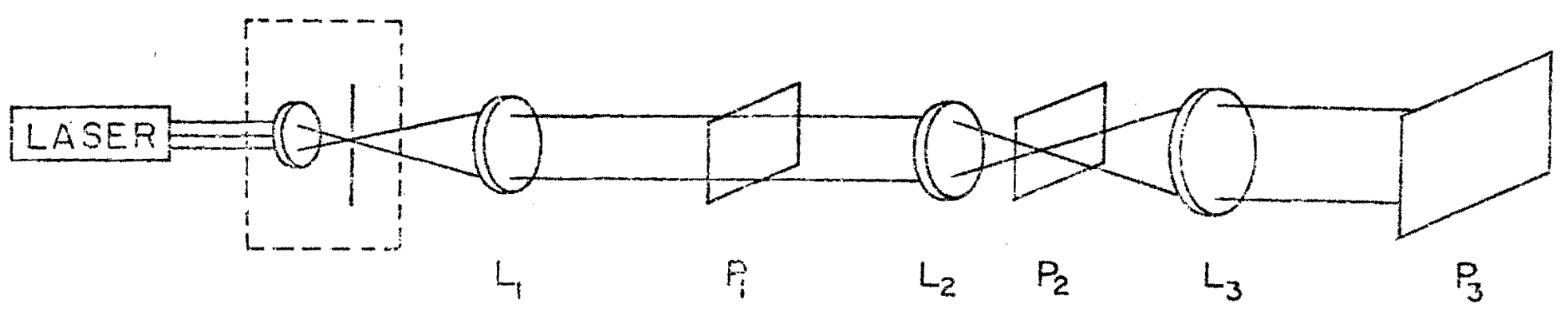

LENS PINHOLE ASSEMBLY

Figure 7. Schematic digram of the optical diffrectometer appnratus. 
TABLE I

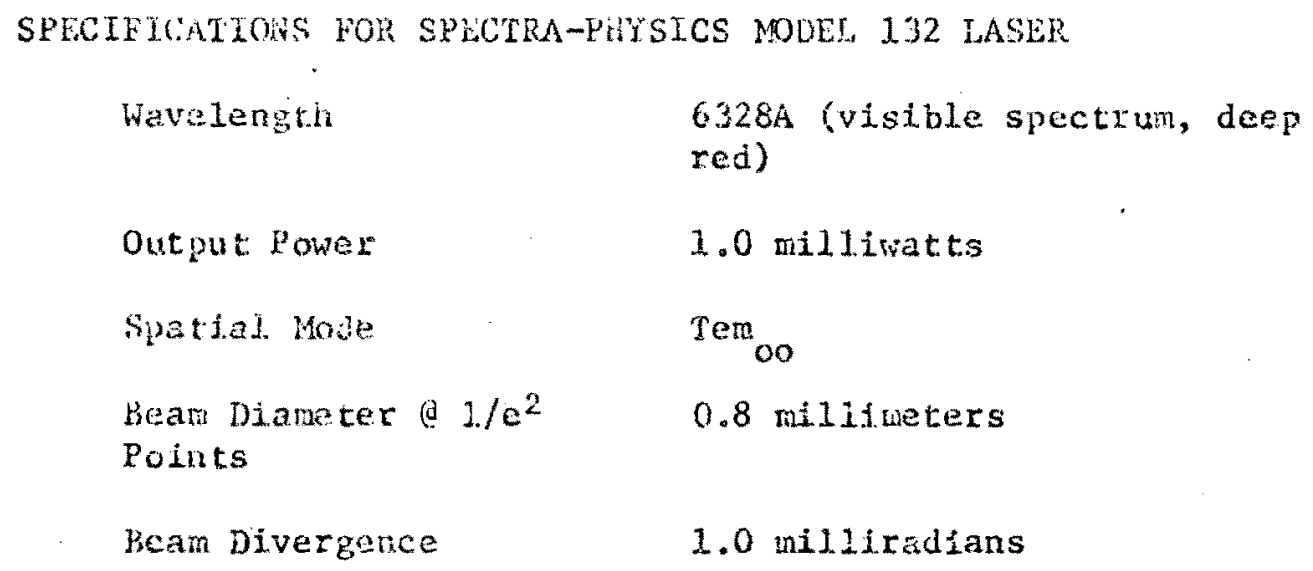

In the plane $P_{1}$ is the input $f i l m$, usually contatned in a liquid gate assernbly. A fluid whose iniex of refraction matches that of the film base and/or emwlyion is used to elingnate phase noise - the randon varlation of optical phase across the film caused by variations in flln thickness. Since in this appaxatus no Liquid gate assembly was used, variacion in filw tilickness was a source for some error. Lens $L_{2}$ extracts the fouriur transforn of the input filn and presents it as a complex ampitide distribution in the plane $P_{?}$, the Fourier tansform plank The optical diffration pattern can be recorded in the plane "2. Cuerally, the diffraction pattem in the plane $p_{2}$ is difficult to a esolve adequately. A convergent lens $L_{\text {? }}$ vas used to magnify the diffraction patern and position it in the tinal plane $\mathrm{P}_{3}$. The plane $P_{2}$ is losated a datance beind $L_{2}$ equal to the focal length of $I_{2}$. laylor (7) has listed the doal conditions for the attainnent of eptical diftaction patakis in the opticad diffratoneter. In

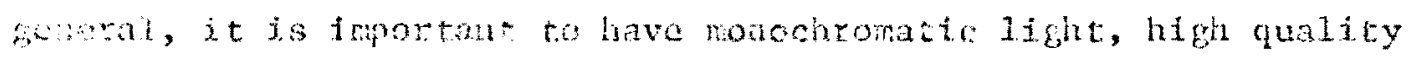


lenses and proper alignment of the system. Precautions were taken to approach these ideal conditions. Lenses were chosen which were free from bubbles and minute inperfections. In addition, care was taken to Insure the lenses were clean and free from grease spots and condensation. The Spectra-Physics Lodel 132 Laser provided a sufficiently intense source of monochromatic, coherent light. Finally, the diffraction apparatus was aligned so that all the components of the system had a comon optical axis. Focusing is generally a very critical operation in this type of apparatus. 


\section{CHAPTER V}

\section{DATA}

A Cornell Intexference and Diffraction Slitfilin Demonstrator was used as a reference pattern for the camera coustant method of analysis. The particular spacing chosen consisted of 14 slits with a center to center spacing of $0.0176 \mathrm{~cm}$. The diffraction pattem genexated from this set of slits had princtpal maxima with separations of $1.0837 \mathrm{~cm}$. Usjug Equation 6 , it was determined that the camera constant for this particular position of camera and magnifying lens was $0.01907 \mathrm{~cm}^{2}$. This camera constant was used in al1 calculations related to the optical diffuction pettern analysis, since the position of the cumora and the magnifying lens was not changed in tha apparatus.

A sexies of pinotographs was taken for each area of the electron microgkaphe from winch an optical diftraction pattern was obcalined. Whese photographs consisted of a general area from which tire optical diffraction pattern was olitined, the area enclosed by the mask whis contalued the scattering objects for the opticel diffraction patterns and the optiogl diffraction partern iteelf.

Sone general feabures of the diffraction patterns are vorth comenting upor. The intense centeal region is contributed to not only by ine zero order difracted bean but also the halation ring anining from reflections of this bon at the back surface of the

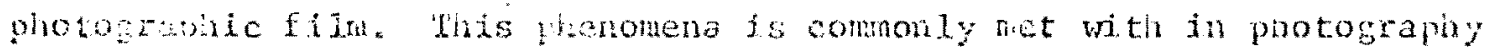


of etrong sources of light. The two, approxinately perpendicular: spikes of high futensity which pass through tha center of the diffraction pattern represent the apetture function of the subject, 1.e., the diffraction pattern of the mask used to frame tha region j.Huninated. Because the short and of the mask has not always besa set strictly perpendicular to the long edge, these spikes are nct necessarily mutully orthogonal. The very fine perlodfcicies within the spikes are functions of the nask dimensions. The use of the mask euables one to rotate the optical diffraction fattern into the inage so that the particular planes in the iage can be identified.

A sumary of the data restilting from the analysis of the optical diffracton pacterus is listed in Tables II and III. Table IX shows a comparison of the possible plo:s spacings for p-Lactoglobutin crystajline naterial using the lattice paramaters of senti and harner (.2) and those plane spacings which were determined experinentally. The cheoretical and experimental values for the angles between the possible planes are listed in Table IIl. The data was dotemines to be consistent if plane apacings and angular relations were both resechably close to the $x$-ray results.

Fisure 8 is a print oblained trom an electron microrraph of

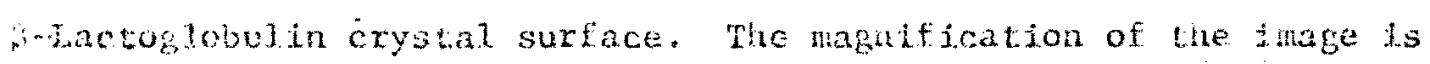
$168,000 \%$ and the magnification of the insert is $336,000 x$. Figure 8 shows the (110) and (Ol2) planes for B-Lactoglobulin. Althongh the imoce appears to be quite structured, the priojicticy is not ruadjly aphent. Figure 9 shows a photograph of the optical disfraction 
TABIEE II

CORPARISON OF POSBIBLY PUANS RESOLVABLE

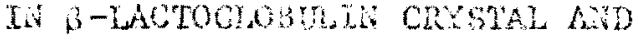

EXWRIMLTAL

Resuts

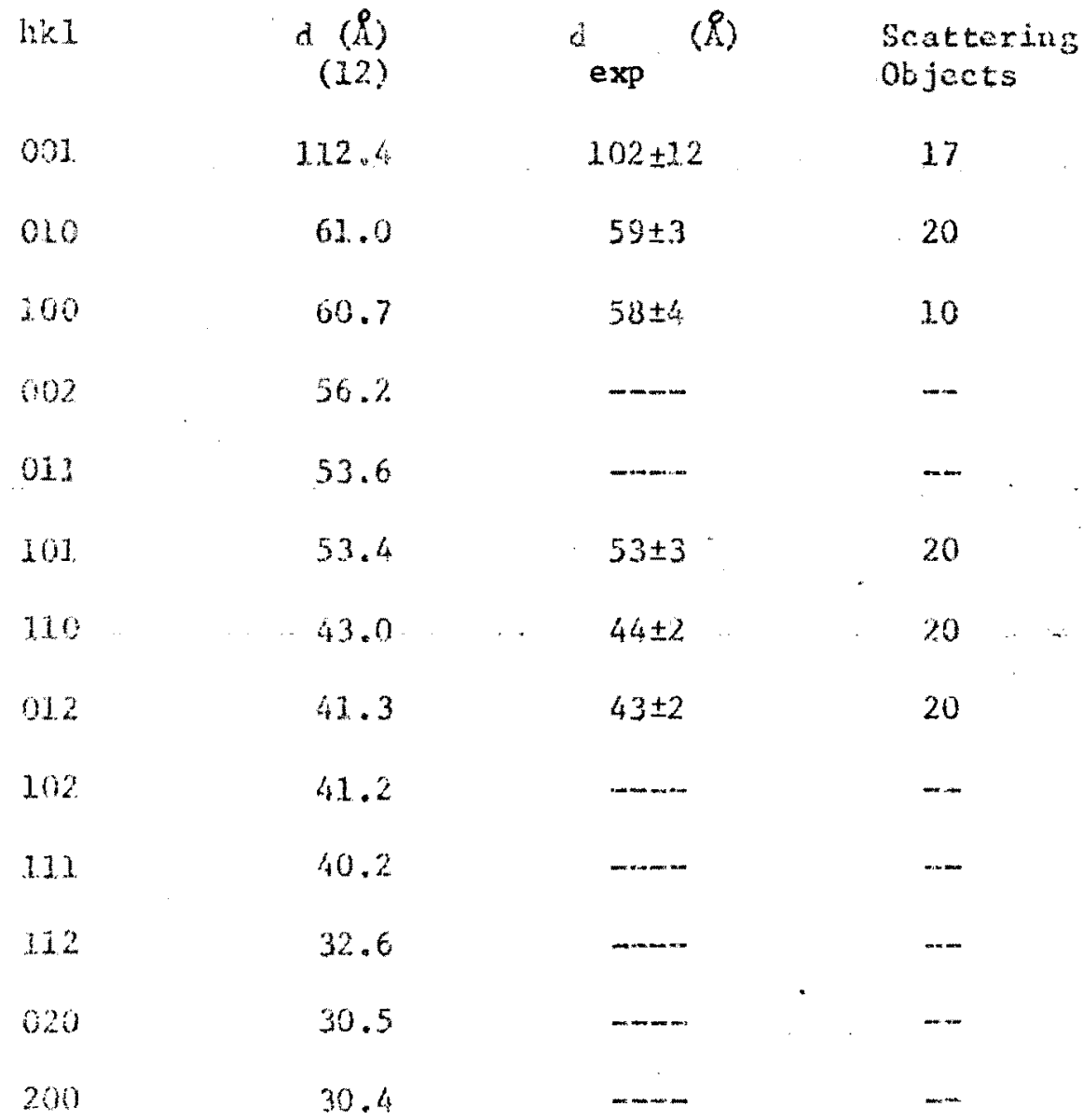

HABLE III.

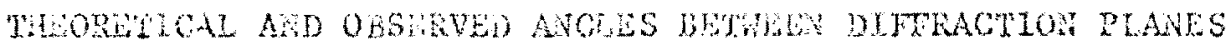

$\begin{array}{lcc}\text { PLANES } & \text { ANGLE } & \text { AriLL meacured } \\ (010),(101) & 90^{\circ} & 89^{\circ} \\ (001),(100) & 90^{\circ} & 89^{\circ} \\ (110),(012) & 62.5^{\circ} & 61.5^{\circ}\end{array}$




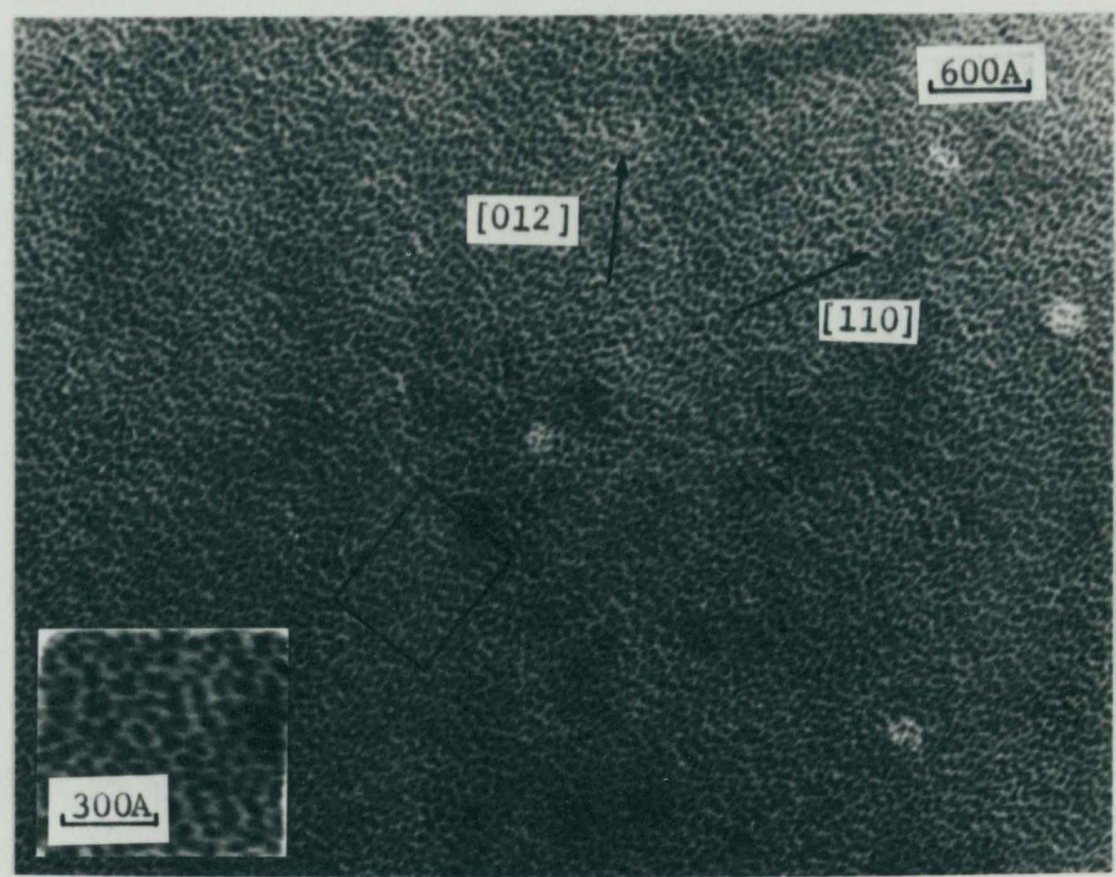

Figure 8. Photograph of electron micrograph area from which the optical diffraction pattern in Figure 9 was obtained with the insert showing the mask area. The arrows indicate the [110] and [012] directions.

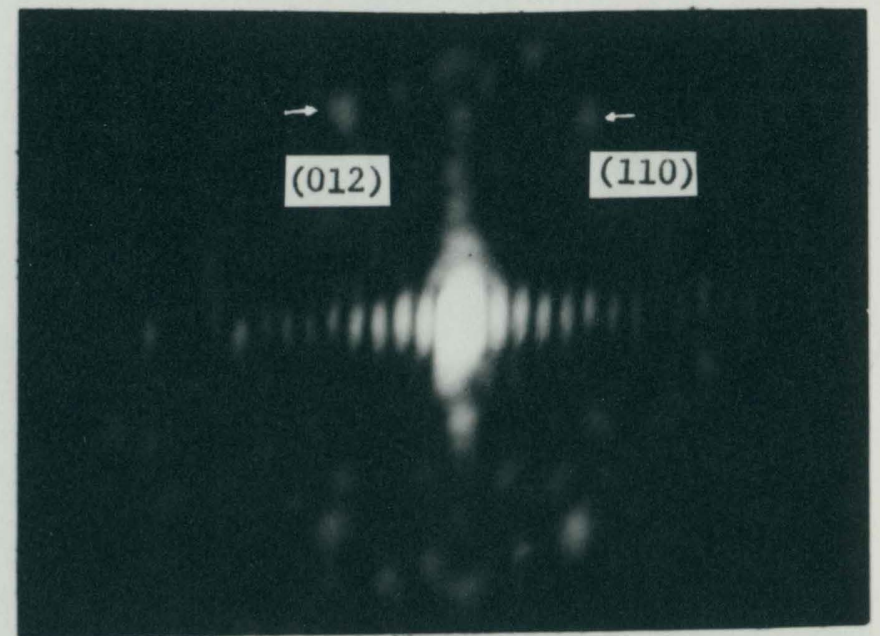

Figure 9. Photograph of optical diffraction pattern of $\beta$-Lactoglobulin showing the diffraction maxima generated by the (110) and (012) planes. Magnification 3.3X 
pattern obtained fron the insert ara in Figure 8 . The optical diffaction pattern has been rotatod tinto the inage using the diffraction spot: arising from the rask dimensions to indicate the direction of the repeating structurc giving rise to the diffraction spots associated with clet repeat structure of B-Lactoglobulin. All the opticel diffraction patterna recorded have beev rotated into theix respective tmages.

Figure 10 is a photograph showing the (001) and (100) planes for B-Lactoglobulin crystal. whiface. The surface appears to be both structured and petiodic. The magnitication of the image is 162,000x and the nagnfrication of the insert is 324,000x. Figure 11 shows a piwtogroph of tha optical diffraction pattern associated win the mask areat of the inset in Figure 10.

Figure 12 shows a photograph of the image from which the optical diffaction pattera in Pigure 13 was generated. The magnification of the itage is $143,000 \mathrm{x}$ and the 1nsett $286,000 \mathrm{x}$. This inage shows the (010) and (at) planes for B-hactoglobulin. The image appears to be structurec and periodie.

Figure 14 ath 15 are, respectively, an ins ge showing the (11.0) plane of B-Lactoglobulin and the optical diffraction pattern generated from this itrage. The mandifation of the inage is $168,000 x$ and the finsert is $336,000 x$. Tire inage appears to have structure in $1 t$, honevar, the derstey veriation is great enough to generate a diffraction pattern vhloh is dificult to incerpet. leciluse of tire tope of samie preparation only a linited lumber 


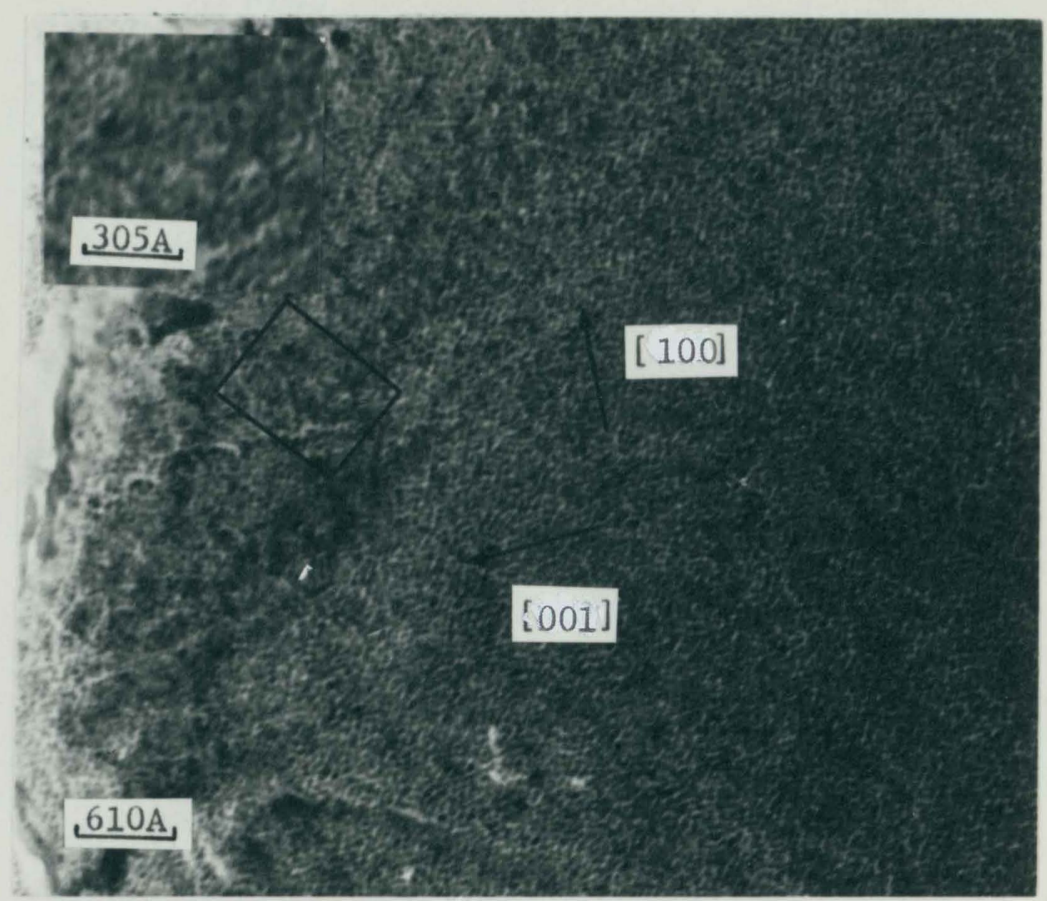

Figure 10. Photograph of the electron micrograph area from which the optical diffraction pattern in Figure 11 was obtained with the insert showing the mask area. The arrows indicate the [001] and the [100] directions.

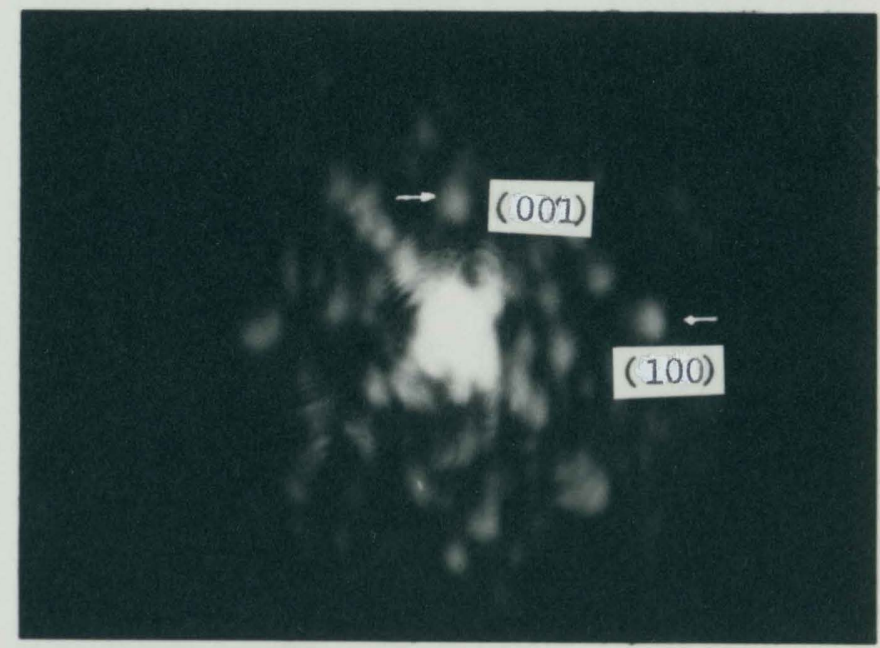

Figure 11. Photograph of optical diffraction pattern of $\beta$-Lactoglobulin showing the diffraction maxima generated by the (001) and (100) planes. Magnification 3.3X. 


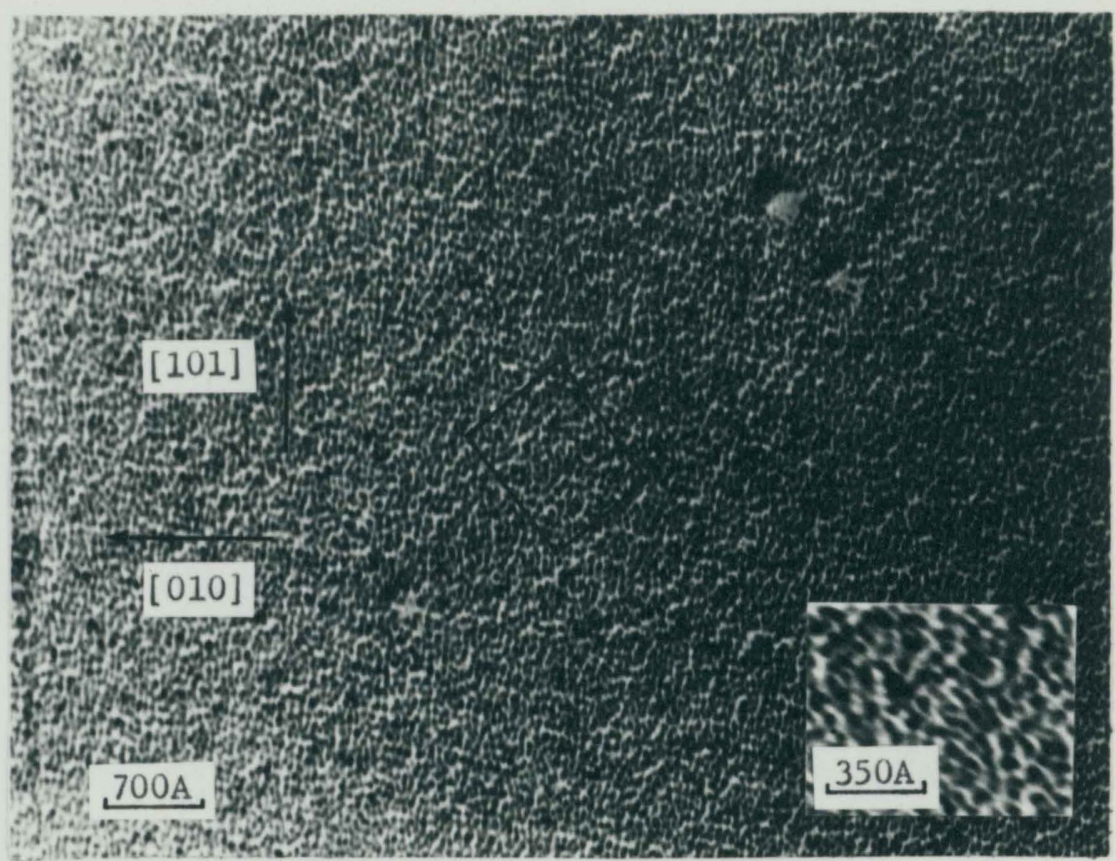

Figure 12. Photograph of the electron micrograph area from which the optical diffraction pattern in Figure 13 was obtained with the insert showing the mask area. The arrows indicate the [010] and [101] directions.

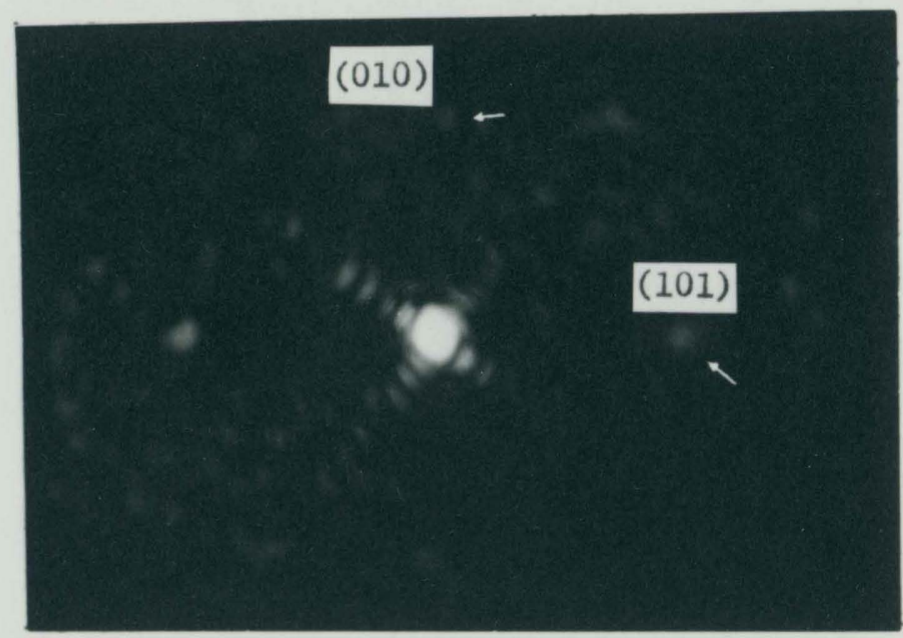

Figure 13. Photograph of optical diffraction pattern of $\beta$-Lactoglobulin showing the diffraction maxima generated by the (010) and (101) planes. Magnification 3.3X. 


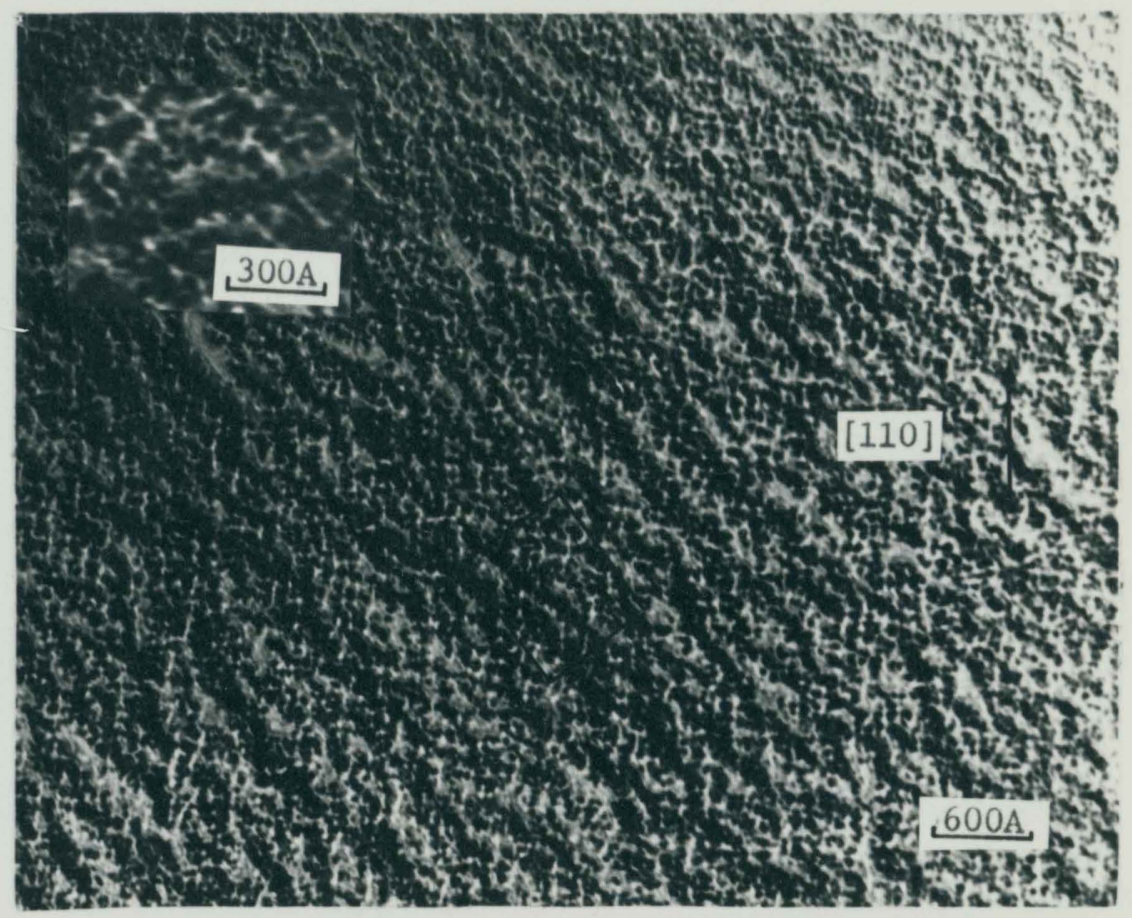

Figure 14. Photograph of the electron micrograph area from which the optical diffraction pattern in Figure 15 was obtained with the insert showing the mask area. The arrow indicates the [110] direction.

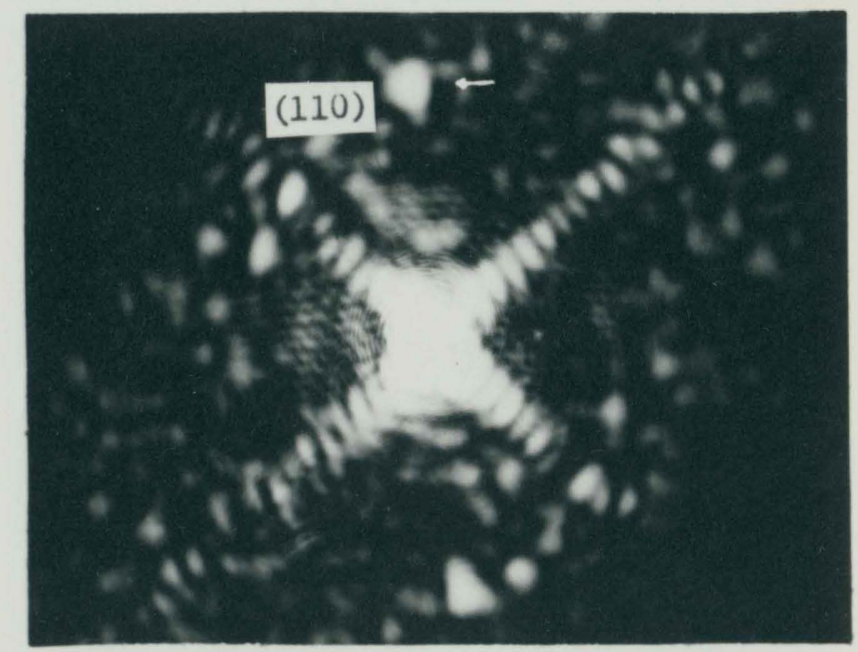

Figure 15. Photograph of optical diffraction pattern of $\beta$-Lactoglobulin showing the diffraction maxima generated by the (110) plane. Magnification 3.3X. 
of diffraction pattens were obtained. The nuber has not sufficient to allow the combination of diffraction pattems with identicaJ periodicties. Howevex, since the structure of $\beta$-lactoglobulin is know from X-ray diffraction analysis, the optical diffraction patterus can be ued to deternine the section of the three dimensional. uint cell structure from which these diffraction patterns could be generated. The zesolution of the replica will linit the number of possible planes, so that it is fairly easy to wite down all the plane spacings and the anguar relations. One chen accepts those planes Wicn are consistent with the knom spacings and eliminates the others for any particular diffracion pattern. This process is repented for each optical dés action metern. With three different wo dinewsinal diffrotion patterns, the unit cell stucture can be recorstructed. 
CHAPTER VI

DISCUSSYON OF THE RESULTS

I. DATA NHAISSIS

Several problems had to be oversoue in sarple preparation. The electron images images obtained were not of as high quality as Dawson's (16). Since the crystalline material was not freshly cleaved, it is possible that there may have been contaminants on the surface of these crystals. In addition, there is some uncertainty in the lattice parameters because of the probable reduction in water content for the crystalline material exposed to the vacuum environment.

Both the dersicy and spacing variation can lead to exrose in the whit cel. 1 structure determination. This effect occurs because the oftical diffraction method of dralysis responos to all vatiations in tha object without discrintnatiug between then. The resulis is that the epacing between the zoro order difiraction spot and the diffraction spet af infurest will represent the rectprocal of an average spacing. Was vactations in the electron micrographs resulted in opriad diffraction patteras which exhiblted a great aieal of notse or backgoud fintensty, the diffraction maxima were not as stomg as they could have been, bohil because of the variation in the repeating structere and donsty and because of the limited number of acstoring bijects. 
Because of the linited nuber of scattering objects, the elonqation values ranged fron $5 \%$ to $10 \%$ ot the experimentally derecmata lattice paraneters. No difficultes arose, related to elongetion, conceming the selection of on pinte as opposed to anther for a particular HIler index because of the limlted number of planes possibje.

\section{Conchuston}

Electron micrograpts and ontical diffraction pattens were recorded which ware found to be consisfent with the structure of B-Lactoglobulin as deterained by $\mathrm{X}$-ray diffraction analysis. The unt

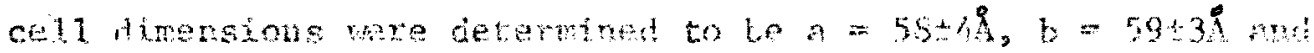
$c=102 \pm 128$.

Sample preparation reinains the rost difflendt problem. In the replica techique, the use of freshly cleaved crystajs would probably redure sone of the problexis.

The unt cell structure deterwination of a noteriaj wose parindicsty is destroyod when it is renoved roris its nativa

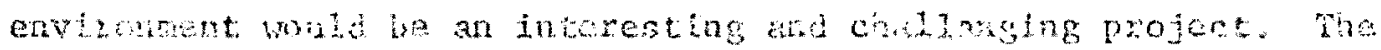

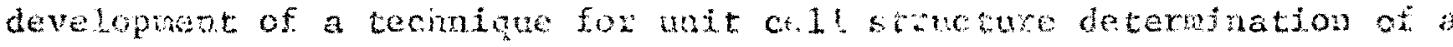

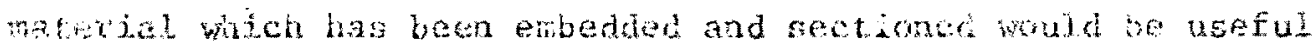

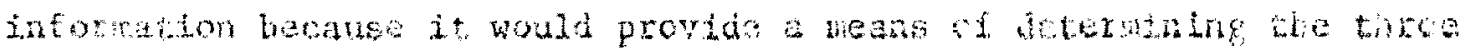

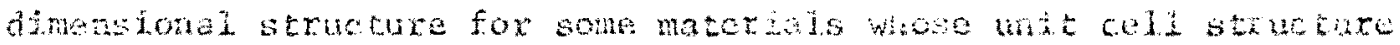

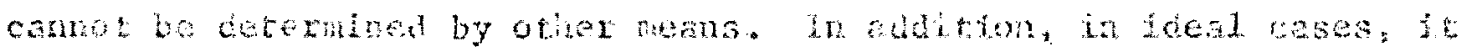

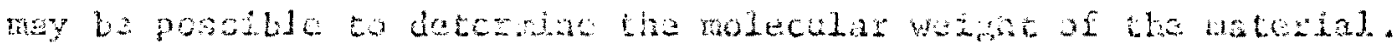




\section{REETRPCES}

1. D. I. DeRosier and A. Klug, "Reconstruction of Three Dimensional Structures from Rlectron Micrograpis": Nature, Vol. 217, (January 13,2968$), 230-134$.

2. Jacob E. Berger, "Optical Diffraction Studes of Crystadilue Structures in kilectron Micrograpis: I. Theoretical Cousicterations", The Journal of Ce11 Biology, Vol. 43, (1969), $442-447$.

3. R, Markhain, S. Frey and G. J. Hills, "Hethods for the Enhancement of lnage Detail and Accentuation of structure in Electron Nicroscopy", Virology, Vol. 20, 88-102.

4. R. Markhan, Virus, Nucleic Acids and Cancer, Baltinore: the Milians \& Wilkins Company, (1963).

5. R. Heiknan, $B$. H. Hitchborr, G. J. Hills and S. Krey, "Whe Aratomy of the Tabacco Mosaic Virus", Virology, Vol. 22, 342.

6. A. Klug and I. E. Berger, "An Optical Nethod for the Analysiss of Periodicities in Electron ificrogrephs, and Some observations on the Hechanism of Vegative Staining", Journal of Molecular Biolouy, Vol. 10, (1964), 565-569.

7. C. A. Taylor and H. Lipson, Optical Transforms: Their Preparation and Application to X-ray Diffraction Problens, New York: Conel1 University Press, 1964.

8. J. L. Berger and C. R. Zobel, 'Laser as a Light Source for orical biffractumeters; Fourier Analysis of Llectron Wiurograph", Sclence, Vol. 150, (July \&, 1966), 168-170.

9. R. W. Janes, The optical Principles of the Diffraction of X-rays. London: 6. Leld and Sons kta., 1953.

10. Irmin Sternjieb and Jacob E. Berger, "Optical Diffraction Studies of Cxystallina Structures in Vlectron Micrographs: II. Crystallne IncJusions in Vituciondria of liman lepatocytes", Lournal of cell biology, vol. 43, (3969), $448-455$.

1. Francis A, Jenlinis and laxvey E. White, princigles of optics, Nev York: McGraw Hill book Company, 1957. 
12. F. Sonti and B. C. Waner, "k-ray Nolesuler Veight of

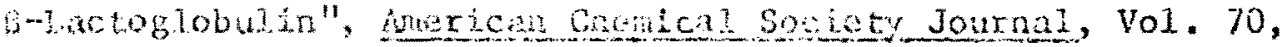
$(1948), 3318-3320$.

33. D. F. Milay, "Cryatal Seructure of a Low Molecular Weight

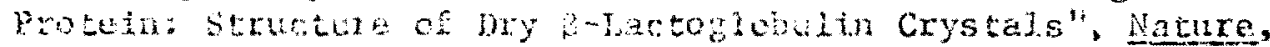
(Atrust 11, 2.951), $242-243$.

14. D. Growoot and D. ililey, "Cryetal. Structures of the Proteins", iture, vol. 41, (Morch 19,1933$), 521-324$.

15. I. Fonkwien, "X-riy ani optic Measurements on B-Lactoglobulin", Anerican Cherical Snciety Juurnal, Vol. 64, (1942), 2504-2505.

16. I. W. Mason, "Crystnl Btructure of a Low Molecular Weight Pconetn: Electron bictoscoy ổ b-Lactoglobulin cryetals", Nature, (hupust $1.1,3.551), 26.242$.

17. C. B. Hall, Introlucton to Electron Microscony, Nev. York: Megraw-idil Book Comany, 1966. 